\title{
交通量を考慮した航路幅の決定についてーII．
}

\author{
成 俞昶*・井上 欣三** 世 世良 亘**
}

\section{The Determination of Route-Width in Consideration \\ of Traffic Volume - II.}

Yuchang SEONG, Kinzo INOUE and Wataru SERA

\begin{abstract}
Recently, environmental stress in port area strengthens with traffic volume increasing. In addition, the available route-width becomes narrow because of the enlargement and the specialization of vessel relatively. Therefore, it's necessary to access the route-width in the view not only of a ship motion but also of traffic congestion.

The design method on route-width focuses on the maneuvering of a maximum size ship now. But, this method is not clear on safety because a lot of various vessels exist and pass in same route. To solve this problem, we suggested in the former report how to determine the route-width in consideration of traffic volume near shore.

In this research, we set the traffic volume and speed in harbour and carried out simulation in one-way and two-way route. The results showed as relation between route-width and traffic volume. And these lead us to estimate the route-width including the effect of traffic congestion.
\end{abstract}

Keywords : marine traffic engineering, traffic volume, route-width, maritime traffic simulation, environmental stress model

キーワード: 海上交通工学，交通量，航路幅，海上交通流シミュレーション，環境ストレスモデル

\section{1. はじめに}

近年、船舶の大型化・専用化が進み、港内水域を 含んだ海上交通や港湾の様相にも多くの変化が起き ている。特に、港湾の入り口などの港内水域にあっ ては多数の船舶が航行しているので、交通輻輳によ る航行困難性が増えている。この問題を解決するた めに適切な航路幅の設計及びその安全性の検討が必 要である。

しかし、既存の航路幅設計法の場合、その航路を 通航する大船型 1 隻を対象とし、その船舶 1 隻の運 動を考慮した設計であり、多種多様な船舶が混在し て航行する現行航路に対して、その幅員がどれほど の安全性を確保しているかについては 明らかでは ない。

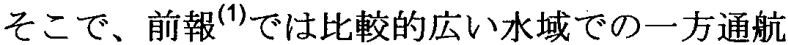
の航路を想定し、避航のある交通流シミュレーショ ンを実施して航路幅と許容交通量の関係について検 討した。その結果、1 隻の最大船型の船舶を対象に して決められた航路幅がどれほどの交通輻軞状態ま で安全性を保証できるのか、逆に、交通量によって どれほどの航路幅が必要になるかがわかった。しか し、港内航路のような制約水路における交通流では、 船舶の航行速力、船型構成比、通航方式など広い水 域での航行形態と多くの差があり、その影響を考慮 した航路幅の決定が必要である。

本研究では、港湾における出入り口航路を想定し て、避航のある交通流シミュレーションを実施し、 航路幅と許容交通量の関係について検討する。さら

* 学生会員 神戸大学大学院 自然科学研究科 (广658-0022 神戸市東灘区深江南町 5-1-1)

** 正会員 神戸大学大学院 海事科学研究科（广658-0022 神戸市東灘区梁江南町 5-1-1） 
に、この考えを現行航路に適用して、既存の航路設 計法による航路幅とどのような関係になるかを考察 する。

\section{2. 従来の航路幅決定法 $\left(W_{L}\right)$ と交通量を考 慮した航路幅決定法 $\left(W_{T}\right)$ の検討}

船体運動を考慮した従来の航路幅決定法としては、 国際的にはPIANC Rule ${ }^{(2)}$ そして、日本では港湾の

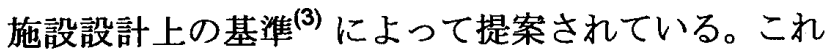
らの規定では、航路幅の設計の時、対象船舶の基本 操船幅、正横風、潮流、波の影響、ブイの航行サポ 一ト施設、貨物の種類、航過距離、岸壁余裕距離な どが算定要素として考虑され、一般的に航行幅は船 舶の行き会う可能性のない一方通航航路の場合は対 象船長 L の 0.5 倍、船舶が頻繁に行き会う往復航路 の場合は船長 L の 1.5 倍、それ以外の往復航路では 船長 L の 1 倍を求めている。

この時、その航路を航行する最大船型の運動を対 象に算定しているので、他船と競合して航行する船 舶輻輳という概念は考慮されていない。しかし、航 路には多種多様の船舶が存在して、時間帯によって は交通輻輳によって非常に混雑した状態が生ずる。

そのため、このような最大船型の船舶を対象にし て航路幅を決める方法だけでは、交通輻軑時にはそ の航路の安全性に関しては問題が生じる恐れがある。

そこで、港内航路のような比較的狭い水域におい て交通輻輳状態が予想される航路の場合、最大船型 船舶の運動を考虑して決めた航路幅と航路内の総交 通量を考慮した航路幅との関倸を調へ、既存の設計 方法による航路幅ではどれほどの交通量までを許容 できるのか、また交通量の増加によってどれほどの 航路幅が必要と成るのかを明らかにする研究が必要 と考えた。両者の考え方を式で示寸と、次式のよう に表現できる。

$W_{L}=W_{1}+W_{2}+\sum_{i=3}^{n} W_{i}$

$W_{1}$ : 航路内最大船型の基本操船幅

$W_{2}$ ：往復通航対応幅

$W_{i}$ ：交通環境対応幅（岸壁、潮流、波など）

$W_{T}=\alpha \cdot Q_{L}+\beta$

$Q_{L}:$ L 換算交通量

$\alpha, \beta$ : 航路条件による係数
港内航路状況を再現するため、前報に準じて避航 がある海上交通流シミュレーションを実施した。避 航モデルは一般的に利用されている好ましさモデル を利用した ${ }^{(4)}$ 。シミュレーションの設定条件を以下 に示す。

設定海域はFig.1に示すように長さ10,000m とし、 評価区間は航路中央を基軸にした 4,000m とした。 交通進行方向は一方通航と港内航路で一般的な分離 通航のない往復通航を設定した。実施時閒は信頼性 が高い評価結果を得るためには充分に長い時間が必 要であるが、ここでは計算効率等も考慮し、各シミ ュレーションの時間は交通量に関わらず、100 時間 とした。

航路幅は日本の主要港湾に関する航路幅を調查し た結果、おおよそ $300 \mathrm{~m}$ から $600 \mathrm{~m}$ だったので、本 シミュレーションでは $300 \mathrm{~m} 、 500 \mathrm{~m} 、 700 \mathrm{~m}$ の 3 パターンで実施した。

船舶の船型構成に関しては様々な分類方法がある が、神戸港に入港する船舶の実態観測データ ${ }^{(5)}$ をも とに、小型船 $(1,000 \mathrm{GT}$ 未満、長さ $48 \pm 20 \mathrm{~m})$ 、中 型船 $(1,000 \mathrm{GT} \sim 10,000 \mathrm{GT} 、 104 \pm 20 \mathrm{~m})$ 、大型船

$(10,000 G T$ 以上、 $240 \pm 50 \mathrm{~m})$ の 3 種類とした。

それぞれの速度については港内速力を想定し、小 型船は $10.0 \pm 3.1 \mathrm{kts}$ 、中型船は $8.3 \pm 1.1 \mathrm{kts}$ 、大型 船は 7.2 $\pm 0.8 \mathrm{kts}$ とした。なお、船舶の発生時間間 隔は目標発生隻数に応じた平均発生時間間隔を求め、 そのような平均値を持つ指数分布を用いて船舶を発 生させている。

船型構成比は小型: 中型:大型で分け、7:2:1、4:5:1、 4:3:3の 3 つのパターンで実施した。

このようなプロセスによって合計 162 パターンの シミュレーションを実施した。この交通流データに 環境ストレスモデルを適用した評価を行い、航行困 難性の面からその影響を分析した。
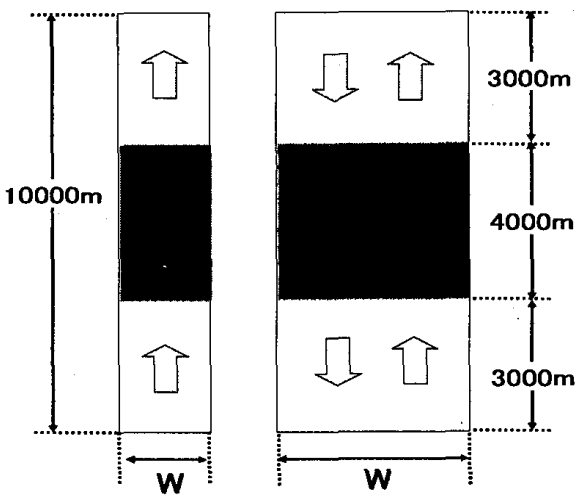

Evaluation Area

Fig. 1 The way of traffic flow (One-Way and Two-Way) 


\section{4. 評価結果の分析}

\section{1 評価指標と許容基準}

評価指標には、交通輻輳中での操船困難性を現わ 寸評価指標として環境ストレスモデルによる環境ス トレス值を採用した。環境ストレスモデルは、さま ざまな要素で構成される周辺環境が操船の困難さの 面から操船者に課す負荷の程度を定量的に評価する ための方法として開発された。このモデルは、自然 条件、地形条件、施設条件、交通条件など操船者を 取り巻く周辺条件が操船者の行動を制約する際、操 船者に課される負荷の大きさを 0 1000 の範囲の 数值により定量的に評価するモデルである(6)。

シミュレーション結果から出力される器境ストレ 又値に対する許容の可否を判断する条件として、操 船者集団の 8 割が許容できない状態に相当する環境 ストレス值が 890 と求められており、その出現率

【P(ESA $\geqq 890) 】 を$ 判定の指標として採用した ${ }^{(7)}$ 。 なお、該当航路幅条件の下における許容可能な交通 量の限界判定には、特定することができない不確定 要因の存在を考慮する意味から【P(ESA ミ890)】が
5\%以内を許容の範囲内とした。

\section{2 評価結果}

\subsection{1 航路幅に対する許容交通量の算定}

Fig.2 は一方通航と往復通航をする航路において、 航路幅ごとに、船型構成比の差によって変化する交 通量と許容できない負荷【P(ESA $\geqq 890) 】$ の出現率 を現わしたものである。船型構成比の異なる交通量 の評価に対して、小型船、中型船、大型船を同じ 1 隻の交通量と考えるのではなく、長さ $70 \mathrm{~m}$ の船舶を 標準船型と決めて、各通航船舶を $L$ 換算して交通量 を基準化した ${ }^{(8)}$ 。

まず、図中上段の $(A)$ は、一方通航の場合を現わし、 航路幅が $300 \mathrm{~m} 、 500 \mathrm{~m} 、 700 \mathrm{~m}$ の 3 つの航路幅で区 分して、自船船型をパラメータにして【P(ESA ミ 890)】の值をプロットしたものである。図中下段(B) は往復通航の場合であり、(A)と同じく各航路幅別で 自船船型をパラメータにして【P(ESA ミ890)】の值 をプロットした。一方通航に比べて往復通航の場合 は全般的に ES 值が高い事が分かる。

\section{$<$ A. One-Way $>\quad 300 m$}

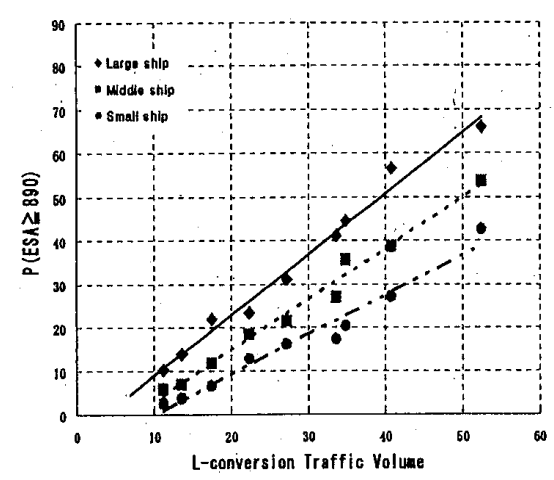

$<$ B. Two-Way $>\quad 300 \mathrm{~m}$

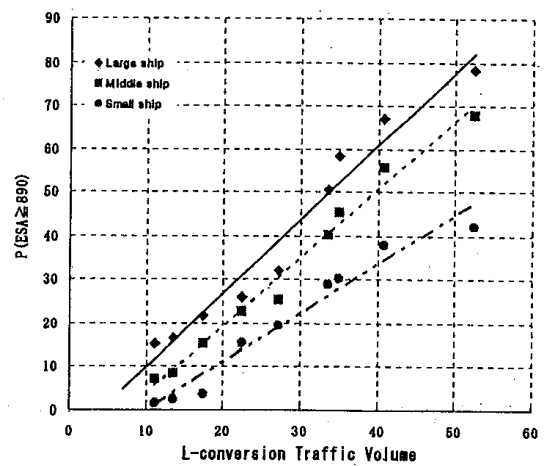

$500 \mathrm{~m}$

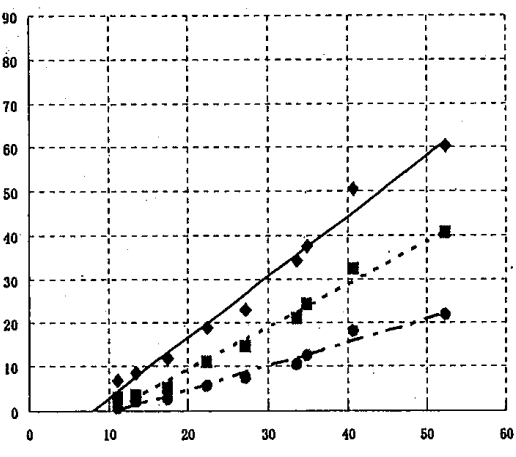

$500 \mathrm{~m}$

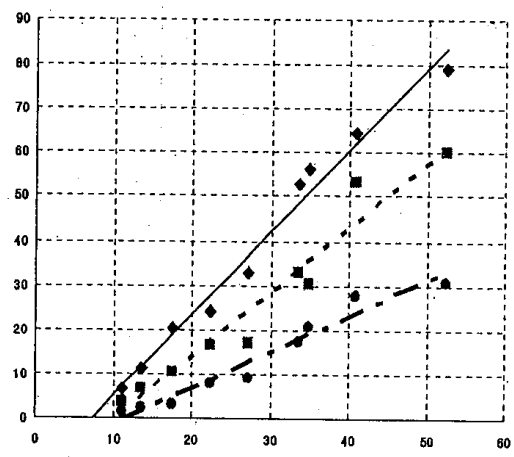

$700 \mathrm{~m}$

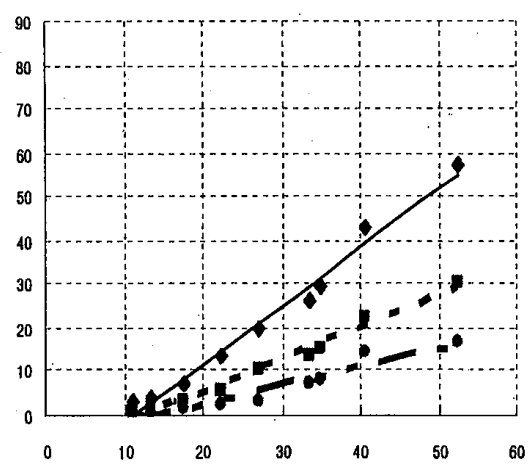

$700 \mathrm{~m}$

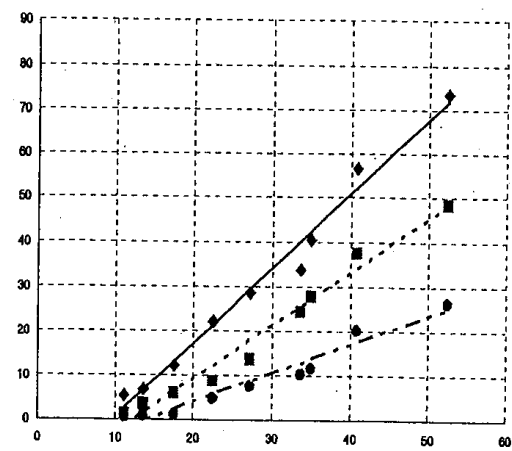

Fig. 2 Rate of appearance of $P\left(E S_{A} \geqq 890\right)$ according to width of route 


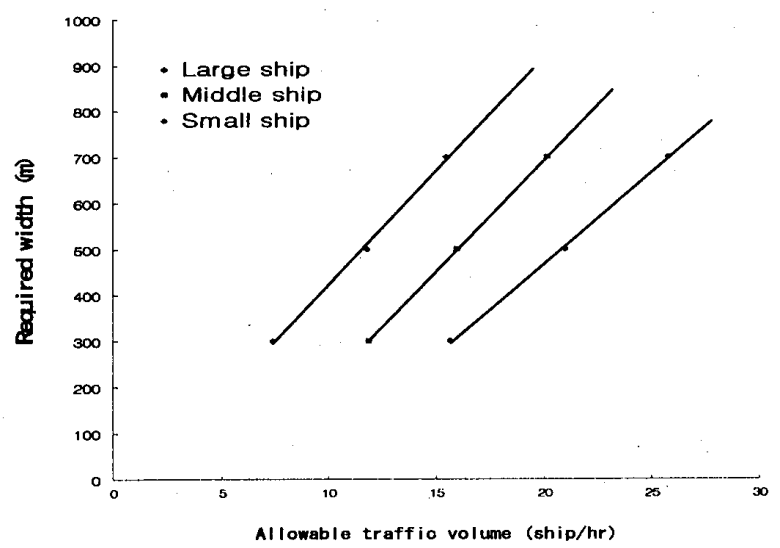

Fig.3 Relation between width of route and traffic volume (One-Way)

なお、それぞれの図は、船型構成比が<7:2:1>、 $<4: 5: 1>$ 、 $<4: 3: 3>$ の場合の交通量を、 $L$ 換算交通量 を利用して基準化してプロットしている。そして、 それぞれの自船船型ごとに 9 点を 1 つのグループと して直線回帰を実施した。

これらの図をもとに、自船が大型船と中型船、そ して小型船の場合に、各交通量に応じて課される負 荷の大きさを示す回帰直線が縦軸【P(ESA $\geqq 890) 】$

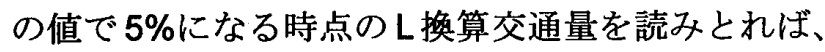
各航路幅に対する許容交通量を得ることができる。

\subsection{2 許容交通量に対する必要航路幅の推定}

Fig.2 より、大型船、中型船、小型船のそれぞれか らみた各航路幅における許容交通量を求めることが 出来るので、これらの值を基に、自船の大きさごと に許容可能な交通量に対応する必要航路幅の推定を 行うこととした。

Fig.3 と 4 は、一方通航の場合と往復通航の場合 について、許容交通量と必要航路幅の関倸をプロッ トした図である。これらの図をもとに、自船が大型 船、中型船、小型船のそれぞれの場合について、許 容交通量から必要航路幅を求めるための推定式を求 めた。

Fig.3 と 4 を利用して自船船型毎に求めた交通量 と必要航路幅の関係は式(3)、(4)のようになる。

<一方通航の場合 $>$

$$
W_{T_{\mathrm{t}}}=\alpha \cdot Q_{L}+\beta
$$

$\begin{array}{lll}\text { 大型船 } & \alpha: 49.26 & \beta:-69.78 \\ \text { 中型船 } & \alpha: 46.19 & \beta:-272.65 \\ \text { 小型船 } & \alpha: 39.57 & \beta:-324.41\end{array}$

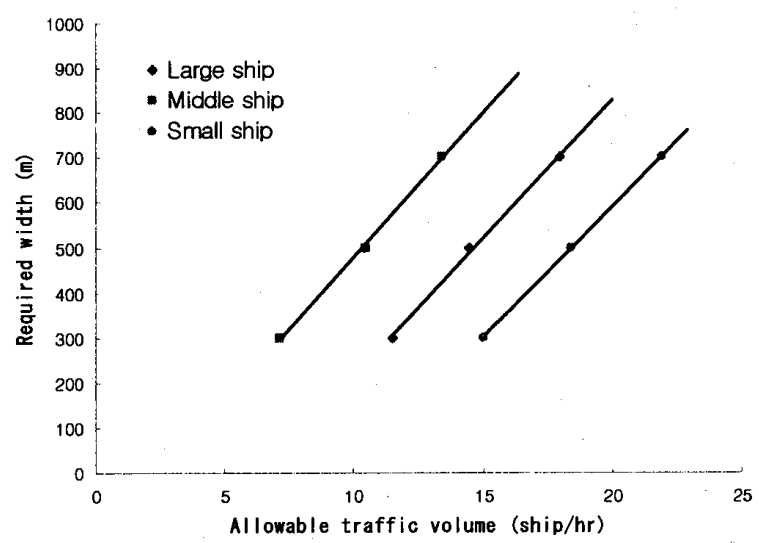

Fig.4 Relation between width of route and traffic volume (Two-Way)

＜往復通航の場合＞

$$
W_{T_{2}}=\alpha \cdot Q_{L}+\beta
$$

$$
\begin{array}{lll}
\text { 大型船 } & \alpha: 68.82 & \beta:-159.34 \\
\text { 中型船 } & \alpha: 61.42 & \beta:-400.79 \\
\text { 小型船 } & \alpha: 57.76 & \beta:-568.52
\end{array}
$$

\section{5. 実際の航路への適用例}

前章で交通輻輳状態を考慮した必要航路幅の推定 式を求めた。ここでは、事例研究として神戸港第 3 航路（現中央航路）の1995 年における航行実態調 査デー夕に基づいて ${ }^{(5)}$ 、航路を通航する最大船型の 運動を考慮した航路幅と本報で提案する交通量を考 慮した航路幅を適用して比較を試みた。

＜航路幅の算出 $>$

（1）従来の航路設計による航路幅 W

航路通航最大船舶（1995 年）: APL JAPAN

64,502GT、Loa : $276 \mathrm{~m} 、 B: 40 \mathrm{~m} 、 \mathrm{D}: 14 \mathrm{~m}$ 必要航路幅

往復通航 : $1.5 \mathrm{~L}=414 \mathrm{~m}$

一方通航 : $0.5 \mathrm{~L}=138 \mathrm{~m}$

（2）交通量を考慮した航路幅 $W_{T}$ 通航船舶数（往復通航）: 23 隻

$\mathrm{L}$ 換算交通量 : 15.23 隻 必要航路幅

往復通航

大型船 : $68.82 \times 15.23-159.34=888.79 \mathrm{~m}$ 中型船 : $61.42 \times 15.23-400.79=534.64 \mathrm{~m}$ 小型船 : $57.76 \times 15.23-568.52=311.16 \mathrm{~m}$ APL JAPANの場合 : $889 \mathrm{~m}$ 


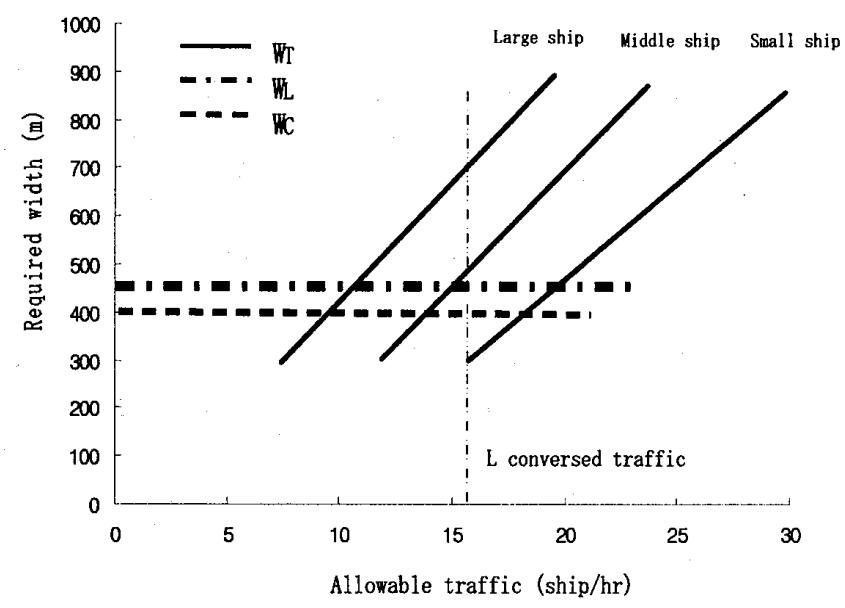

Fig.5 Empirical comparison, measuring $\mathrm{W}_{\mathrm{T}}, \mathrm{W}_{\mathrm{L}}$ and $W_{C}$ (One-Way)

\section{一方通航}

大型船 : $49.26 \times 15.23-69.78=680.45 \mathrm{~m}$

中型船 : $46.19 \times 15.23-272.65=430.82 \mathrm{~m}$

小型船 : $39.57 \times 15.23-324.41=278.24 \mathrm{~m}$

APL JAPANの場合 : $681 \mathrm{~m}$

（3）1995 年当時航路幅 $W_{c}: 400 m$

Fig.5、6に既存の設計法による航路幅 $\left(W_{\mathrm{L}}\right)$ と交通 量を考慮した航路幅 $\left(W_{T}\right)$ 、そして 1995 年当時の 航路幅 $\left(W_{C}\right)$ との関係を表示した。当時の神戸港第 3 航路の場合、最大船型でみれば、従来の設計法に よる航路幅も交通量を考慮した航路幅も、往復航路 としては基準を満足せず操船者に多くの航行負担を 与えていると解釈できる。管制により一方通航にな つた場合でも、交通量を考慮した航路幅は满足して いない。

中型船の航行面でみても、交通量を考慮した場合 は航路幅は不十分であり、小型船の場合にようやく 航路幅は問題がないと解析される。今回用いた海上 交通流シミュレーションのものでは、以上のように 分析できるが、このように交通量を考慮した場合の 航路の設計や、現状の評価を行うことが可能である。

\section{6. 結論}

近年、船舶の大型化・専用化が進行するにつれて 港内水域を含んだ港湾の様相や海上交通にも多くの 変化が進行している。その中で操船者の最も気がか りな点の 1 つが航路幅の問題であろう。既存の航路 幅設計法は航路を通航する最大船型の運動を中心に 設計されているが、実際の航路では多種多様な船舶 が混在して航行するから、どれほど安全性を確保し

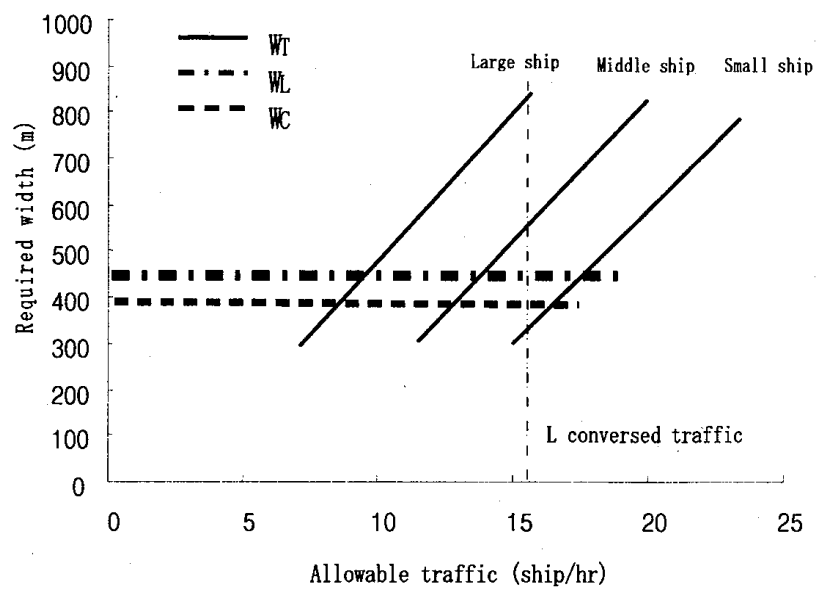

Fig.6 Empirical comparison, measuring $\mathrm{W}_{\mathrm{T}}$, $\mathrm{W}_{\mathrm{L}}$ and $\mathrm{W}_{\mathrm{C}}$ (Two-Way)

ているのかが不明瞭である。

この観点から、本研究では、比較的広い水域を 航行する時の交通量を考慮した航路幅決定の研究に 引き継き、交通混雑が予想される港内航路を対象に して交通量を考慮した航路設計法を提案した。そし て、交通の実際観測したデータを基にしてシミュレ ーションの変数を構成し、実験結果から頻繁な通航 がある交通流に対応する適正航路幅の決定方法を検 討した。

本論文では、まず既存の港湾内航路設計法を整理 し次に港内航路を対象として避航のある海上交通流 シミュレーションを実施した。求めたデータを操船 困難性の面から評価した結果、自船の船型と交通量 により必要航路幅を推定するための方法を提案する ことができた。

さらに、この交通輻輳状態を考慮した航路幅の推 定式を利用して、これを既存設計法の航路幅と比べ たケーススタディを行い、その有用性を確認した。

\section{参考文献}

（1）成俞和・井上欣三・世良亘：交通量を考慮した 航路幅の決定について, 日本航海学会論文集, No.116, pp.25-30, 2007.3

(2) PIANC PTC II-30 : Approach Channels-A Guide for Design, Final report of the joint working Group PIANC and IAPH, in cooperation with IMPA and IARA, supplement to bulletin No.95, 1997.7

（3）(社)日本港湾協会 : 港湾の施設の技術上の基準 同解説 (下巻)，1999.4

（4）長澤明・原潔・井上欣三 : 避航操船環境の困難 
度一I .ーシミュレーションによる評価に向け て一, 日本航海学会論文集, No.79, pp.91-100, 1988.9

（5）(社)日本海難防止協会:神戸中央航路幅設計関連 報告書, 1995

（6）井上欣三・増田憲司・世良亘 : 海上交通安全評 価のための技術的ガイドライン策定に関する研 究一I . 一環境負荷の概念に基づく操船の困難 性評価一, 日本航海学会論文集, No.98, pp.225-234, 1998.3

（7）謝洪涁・井上欣三 - Cemil Yurtoren : 潜在環境 負荷と残存環境負荷の関係についてーI .一直 線状航路における数量関係の推定一, 日本航海 学会論文集, No.112,pp.95-100，2005.3

（8）竹内伝史・本多義明・青島縮次郎 - 磯部友彦: 交通工学, 鹿島出版会, 2000.3

（9）福地信義 : ヒュマンエラ一に基づく海洋事故一 信頼性解釈とリスク評価一, 海文堂, 2007.4

\section{質疑応答}

津金正典（東海大学）：

シミュレーション実施に設定された 3 パターンの 船型構成の違いにより許容航路幅の差異がどのよ うになるでしょうか。

成 俞租 :

本研究では自船を大・中・小型船で区分し、他交 通流をし 換算した上で必要航路幅を算定しました。 今回行った L 換算交通量での整理では、許容判定 基準【P(ESA $\geqq 890) 】$ は船型構成の違いによらず 線形の関係を示しております。

そのため、今回求めた必要航路幅の推定式は船型 構成によりある程度の変化は予想されるものの、 許容航路幅の差異はほとんど無くすべての船型構 成に対応できると考えております。

中村紳也（日本海洋科学）:

興味哚い講演ありがとうございます。シミュレー ションで航路幅を考える場合、シミュレーション の避航モデルが ES 值、又、結果的に航路幅の決 定に影響を与えることがあるでしょうか。(例えば 避航モデル（好ましさモデル）において航路内と いうことから減速に大きなウェイトを置いた場合、 航行速力が低下し、ES 值が小さくなるなど）実 海域での状況に近い行動が再現できるよう、避航 モデル等のチューニングを実施した上、航路幅の 算定をされたと理解してよろしいでしょうか。
成 俞租：

避航モデルが操船の困難さ（ES 值）に影響を与 える可能性は考えられます。特に、比較的広い水 域（自由水域）を航行する時の避航と港湾の出入 口のような制限水域での避航には違いが存在する と考えられます。

本研究では、害海域での状況を再現するために港 内水域の実態観測データを基に交通流を構成しま した。さらに、避航モデルは自由水域での避航ア ルゴリズムに加え、優先権と他船の変針予測を付 加してシミュレーションを実施しました。 